\title{
PEMBATALAN SANKSI DISIPLIN PROFESI KEDOKTERAN OLEH PENGADILAN TATA USAHA NEGARA
}

\author{
Andryawan ${ }^{1}$ \\ ${ }^{1}$ Fakultas Hukum, Universitas Tarumanagara Jakarta \\ Email: andryawan@fh.untar.ac.id
}

\begin{abstract}
ABSTRAK
Dokter merupakan salah satu unsur penting dalam terselenggaranya layanan kesehatan. Penyelenggaraan layanan kesehatan sendiri dimaksudkan untuk memenuhi salah satu kebutuhan pokok manusia, yaitu hak atas kesehatan sebagaimana yang tercantum dalam Pasal 28H Ayat (1) Undang-Undang Dasar Negara Republik Indonesia Tahun 1945. Mengenai layanan kesehatan, khususnya mengenai praktik kedokteran, diatur dalam Undang-Undang Nomor 29 Tahun 2004. Dalam penyelenggaraan praktik kedokteran, setidaknya terdapat 3 (tiga) bentuk pelanggaran, yaitu pelanggaran hukum/malapraktik, pelanggaran etik, dan pelanggaran disiplin profesi dokter. Tulisan ini lebih memfokuskan pada pelanggaran disiplin profesi dokter dan dokter gigi. Pengaturan mengenai disiplin profesi dokter terdapat di dalam Peraturan Konsil Kedokteran Indonesia Nomor 4 Tahun 2011. Dalam hal terjadi adanya dugaan pelanggaran disiplin profesi dokter dan dokter gigi, maka lembaga yang berwenang untuk menyelesaikan masalah tersebut adalah Majelis Kehormatan Disiplin Kedokteran Indonesia. Lembaga ini dibentuk berdasarkan mandat dari Undang-Undang Nomor 29 Tahun 2004. Penegakan disiplin profesi dokter dan dokter gigi yang dilakukan oleh Majelis Kehormatan Disiplin Kedokteran Indonesia tidak jarang pada akhirnya dibatalkan oleh pengadilan tata usaha negara. Metode yang digunakan Penulis yaitu metode penelitian hukum normatif dengan menggunakan analisis yang bersifat kualitatif. Dari penelitian ini, didapatkan kesimpulan bahwa hakim pengadilan tata usaha negara menerima gugatan terhadap Surat Keputusan Majelis Kehormatan Disiplin Kedokteran Indonesia dikarenakan adanya perluasan pemaknaan atau ruang lingkup dari keputusan badan/pejabat tata usaha negara yang dapat diajukan sebagai obyek sengketa di pengadilan tata usaha negara sebagaimana yang tercantum dalam Pasal 87 Undang-Undang Nomor 30 Tahun 2014. Perluasan tersebut membuat penegakan disiplin profesi dokter mengalami kebuntuan.
\end{abstract}

Kata kunci: Dokter, Disiplin Profesi, Majelis Kehormatan Disiplin Kedokteran Indonesia.

\section{PENDAHULUAN}

\section{Latar Belakang}

Profesi dokter dan dokter gigi merupakan profesi yang memiliki keluhuran karena tugas utamanya adalah memberikan pelayanan untuk memenuhi salah satu kebutuhan dasar manusia, yaitu kebutuhan akan kesehatan. Profesi dokter dan dokter gigi yang dahulu dianggap sebagai profesi yang tidak tersentuh oleh hukum, kini mengalami perubahan yang cukup pesat sejak hadirnya Undang-Undang Nomor 29 Tahun 2004 tentang Praktik Kedokteran. Undang-undang ini dibentuk dengan didasari oleh kondisi semakin berkurangnya kepercayaan masyarakat terhadap profesi dokter dan dokter gigi, di mana tidak sedikit ditemukan tuntutan hukum yang diajukan oleh masyarakat terhadap profesi (dokter) ini.

Dalam melaksanakan praktik kedokteran, seorang dokter sangat rentan bersinggungan dengan dunia hukum. Hal ini disebabkan karena profesi ini memiliki hubungan erat dengan kondisi keselamatan seseorang. Menyadari akan kondisi ini, maka dokter pun memiliki imunitas hukum dalam melaksanakan tugas dan wewenangnya, yang mana tidak dimiliki oleh profesi lainnya. Misalnya, dalam hal melakukan tindakan medis terhadap pasien.

Pengaturan praktik kedokteran sebagaimana tercantum dalam Pasal 3 Undang-Undang Nomor 29 Tahun 2004 bertujuan untuk: (a) memberikan perlindungan kepada pasien; (b) mempertahankan 
dan meningkatkan mutu pelayanan medis yang diberikan oleh dokter dan dokter gigi; serta (c) memberikan kepastian hukum kepada masyarakat, dokter, dan dokter gigi.

Memberikan perlindungan kepada pasien sebagaimana salah satu tujuan dari Undang-Undang Nomor 29 Tahun 2004, diharapkan dapat meningkatkan rasa kehati-hatian dokter dalam melaksanakan praktik kedokteran, yang mana tentunya berimbas pada berkurangnya peluang terjadinya Kejadian Tidak Diharapkan (KTD), Kejadian Nyaris Cedera (KNC), maupun Kejadian Tidak Cedera (KTC).

Dalam pelaksanaan praktik kedokteran, setidaknya terdapat 3 (tiga) macam bentuk pelanggaran, yaitu: (a) pelanggaran hukum/malapraktik; (b) pelanggaran etik; dan (c) pelanggaran disiplin profesi dokter dan dokter gigi. Dibedakannya jenis pelanggaran tersebut didasari oleh sumber hukum materiil yang digunakan dan lembaga yang berwenang untuk mengadili ketika terjadi pelanggaran tersebut.

Untuk pelanggaran hukum/malapraktik pada praktik kedokteran merujuk pada ketentuan Kitab Undang-Undang Hukum Pidana (KUHP), yakni ketentuan Pasal 351, 338, dan 359. Selain dari aspek Hukum Pidana, pelanggaran hukum/malapraktik dalam praktik kedokteran juga dapat dilihat dari aspek Hukum Perdata. Dari perspektif Hukum Perdata, tindakan tersebut dapat dianggap sebagai suatu perbuatan melawan hukum sebagaima diatur dalam Pasal 1365 Kitab Undang-Undang Hukum Perdata (KUH Perdata). Ketika terjadi pelanggaran hukum/malapraktik, maka sengketa tersebut diajukan ke pengadilan negeri setempat dengan memperhatikan ketentuan Pasal 118 Herzien Inlandsch Reglement/HIR (untuk perkara perdata) dan asas locus delicti (untuk perkara pidana).

Terkait dengan pelanggaran etik profesi dokter merujuk pada ketentuan Kode Etik Kedokteran Indonesia (KODEKI) sebagaimana yang ditentukan oleh Ikatan Dokter Indonesia (IDI). Ketika terjadi adanya dugaan seorang dokter melakukan pelanggaran etik, maka lembaga yang berwenang menyelesaikan dugaan pelanggaran tersebut adalah Majelis Kehormatan Etik Kedokteran (MKEK) yang merupakan badan otonom dari Ikatan Dokter Indonesia.

Bentuk pelanggaran yang terakhir adalah pelanggaran disiplin dokter dan dokter gigi. Disiplin profesi dokter dan dokter gigi adalah ketaatan terhadap aturan-aturan dan/atau ketentuan penerapan keilmuan dalam pelaksanaan praktik kedokteran. Peraturan Konsil Kedokteran Indonesia Nomor 4 Tahun 2011 tentang Disiplin Profesional Dokter dan Dokter Gigi menentukan setidaknya terdapat 28 (dua puluh delapan) bentuk pelanggaran disiplin profesi dokter dan dokter gigi. Ketika seorang dokter atau dokter gigi diduga telah melakukan pelanggaran disiplin profesi, maka sengketa tersebut akan diselesaikan oleh Majelis Kehormatan Disiplin Kedokteran Indonesia (MKDKI) yang merupakan lembaga otonom dari Konsil Kedokteran Indonesia yang bersifat independen dalam menjalankan tugasnya (Pasal 55 Undang-Undang Nomor 29 Tahun 2004).

Dalam tulisan ini, kajian lebih difokuskan pada penegakan disiplin profesi dokter dan dokter gigi yang dijalankan oleh Majelis Kehormatan Disiplin Kedokteran Indonesia. Hal ini dirasakan menarik karena penegakan disiplin profesi dokter dan dokter gigi ini sering mengalami kebuntuan. Pendapat ini didasari oleh fakta bahwa tidak jarang penegakan disiplin yang dilaksanakan oleh Majelis Kehormatan Disiplin Kedokteran Indonesia kemudian dibatalkan oleh Pengadilan Tata Usaha Negara, bahkan sampai pada tingkat kasasi (Mahkamah Agung) pun demikian, sehingga penegakan disiplin profesi dokter dan dokter gigi mengalami kebuntuan. 


\section{METODE PENELITIAN}

Metode yang digunakan adalah metode penelitian hukum normatif, di mana Penulis mengkaji hukum dengan meletakkan hukum sebagai sebuah bangunan sistem norma. Sifat penelitian ini adalah preskriptif. Data yang digunakan adalah data sekunder yang meliputi bahan hukum primer dan sekunder. Data sekunder tersebut dikumpulkan dengan cara studi pustaka (library research). Selain bahan hukum, tulisan ini juga didukung dengan bahan non hukum berupa wawancara dengan beberapa narasumber dari perwakilan hakim (Pengadilan Tinggi Tata Usaha Negara Jakarta dan Mahkamah Agung), Ikatan Dokter Indonesia (IDI), Konsil Kedokteran Indonesia (KKI), maupun Majelis Kehormatan Disiplin Kedokteran Indonesia (MKDKI). Teknik analisis data yang digunakan adalah analisis kualitatif.

\section{HASIL DAN PEMBAHASAN}

Dalam praktik kedokteran, setidaknya terdapat 3 (tiga) macam bentuk pelanggaran, yang terdiri atas: (a) pelanggaran hukum/malapraktik; (b) pelanggaran etik; dan (c) pelanggaran disiplin profesi dokter dan dokter gigi. Ketiga bentuk pelanggaran ini memiliki konsekuensi yang berbeda pula, baik dari aspek sumber hukum/pedoman yang dijadikan rujukan, lembaga yang berwenang untuk menyelesaikan perkara tersebut, maupun bentuk sanksi yang dijatuhkan kepada si pelaku. Banyak pihak yang memberikan perumpamaan bahwa ketiga bentuk pelanggaran ini seperti pisau trisula. Namun penulisan ini lebih menitikberatkan pada penegakan disiplin profesi dokter dan dokter gigi sebagaimana yang menjadi tugas dan wewenang dari Majelis Kehormatan Disiplin Kedokteran Indonesia.

Majelis Kehormatan Disiplin Kedokteran Indonesia merupakan lembaga otonom yang dibentuk berdasarkan amanat dari Undang-Undang Nomor 29 Tahun 2004 dalam rangka untuk menegakan disiplin profesi dokter dan dokter gigi. Pengaturan lebih lanjut mengenai organisasi dan tata kerja Majelis Kehormatan Disiplin Kedokteran Indonesia diatur dalam Peraturan Konsil Kedokteran Indonesia Nomor 3 Tahun 2011. Majelis Kehormatan Disiplin Kedokteran Indonesia sendiri merupakan salah satu perangkat dari Konsil Kedokteran Indonesia.

Menurut ketentuan Pasal 2 Peraturan Konsil Kedokteran Indonesia Nomor 32 Tahun 2015 dikatakan bahwa penegakan dsiplin profesi dokter dan dokter gigi bertujuan untuk: (a) melindungi masyarakat dari tindakan yang dilakukan dokter dan dokter gigi yang tidak kompeten; (b) meningkatkan mutu pelayanan kesehatan yang diberikan dokter dan dokter gigi; dan (c) menjaga kehormatan profesi kedokteran dan kedokteran gigi.

Dalam menegakan disiplin profesi dokter dan dokter gigi, Majelis Kehormatan Disiplin Kedokteran Indonesia berpedoman pada Peraturan Konsil Kedokteran Indonesia Nomor 4 Tahun 2011, di mana telah ditentukan setidaknya terdapat 28 (dua puluh delapan) bentuk pelanggaran disiplin profesi dokter dan dokter gigi dengan uraian sebagai berikut:

1) Melakukan praktik kedokteran dengan tidak kompeten;

2) Tidak merujuk pasien kepada dokter atau dokter gigi lain yang memiliki kompetensi yang sesuai;

3) Mendelegasikan pekerjaan kepada tenaga kesehatan tertentu yang tidak memiliki kompetensi untuk melaksanakan pekerjaan tersebut;

4) Menyediakan dokter atau dokter gigi pengganti sementara yang tidak memiliki kompetensi dan kewenangan yang sesuai atau tidak melakukan pemberitahuan perihal penggantian tersebut; 
5) Menjalankan praktik kedokteran dalam kondisi tingkat kesehatan fisik ataupun mental sedemikian rupa sehingga tidak kompeten dan dapat membahayakan pasien;

6) Tidak melakukan tindakan/asuhan medis yang memadai pada situasi tertentu yang dapat membahayakan pasien;

7) Melakukan pemeriksaan atau pengobatan berlebihan yang tidak sesuai dengan kebutuhan pasien;

8) Tidak memberikan penjelasan yang jujur, etis, dan memadai (adequate information) kepada pasien atau keluarganya dalam melakukan praktik kedokteran;

9) Melakukan tindakan/asuhan medis tanpa memperoleh persetujuan dari pasien atau keluarga dekat, wali, atau pengampunya;

10) Tidak membuat atau menyimpan rekam medis dengan sengaja;

11) Melakukan perbuatan yang bertujuan untuk menghentikan kehamilan yang tidak sesuai dengan ketentuan peraturan perundang-undangan yang berlaku;

12) Melakukan perbuatan yang dapat mengakhiri kehidupan pasien atas permintaan sendiri atau keluarganya;

13) Menjalankan praktik kedokteran dengan menerapkan pengetahuan, keterampilan, atau teknologi yang belum diterima atau di luar tata cara praktik kedokteran yang layak;

14) Melakukan penelitian dalam praktik kedokteran dengan menggunakan manusia sebagai subjek penelitian tanpa memperoleh persetujuan etik (ethical clearance) dari lembaga yang diakui pemerintah;

15) Tidak melakukan pertolongan darurat atas dasar perikemanusiaan, padahal tidak membahayakan dirinya, kecuali bila ia yakin ada orang lain yang bertugas dan mampu melakukannya;

16) Menolak atau menghentikan tindakan/asuhan medis atau tindakan pengobatan terhadap pasien tanpa alasan yang layak dan sah sesuai dengan ketentuan etika profesi atau peraturan perundang-undangan yang berlaku;

17) Membuka rahasia kedokteran;

18) Membuat keterangan medis yang tidak didasarkan kepada hasil pemeriksaan yang diketahuinya secara benar dan patut;

19) Turut serta dalam perbuatan yang termasuk tindakan penyiksaan (torture) atau eksekusi hukuman mati;

20) Meresepkan atau memberikan obat golongan narkotika, psikotropika dan zat adiktif lainnya yang tidak sesuai dengan ketentuan etika profesi atau peraturan perundang-undangan yang berlaku;

21) Melakukan pelecehan sesksual, tindakan intimidasi, atau tindakan kekerasan terhadap pasien dalam penyelenggaraan praktik kedokteran;

22) Menggunakan gelar akademik atau sebutan profesi yang bukan haknya;

23) Menerima imbalan sebagai hasil dari merujuk, meminta pemeriksaan, atau memberikan resep obat/alat kesehatan;

24) Mengiklankan kemampuan/pelayanan atau kelebihan kemampuan/pelayanan yang dimiliki baik lisan ataupun tulisan yang tidak benar atau menyesatkan;

25) Adiksi pada narkoba, psikotropika, alkohol, dan zat adiktif lainnya;

26) Berpraktik dengan menggunakan surat tanda registrasi, surat izin praktik, dan/atau sertifikat kompetensi yang tidak sah atau berpraktik tanpa memiliki surat izin praktik sesuai dengan ketentuan peraturan perundang-undangan yang berlaku;

27) Tidak jujur dalam menentukan jasa medis; dan

28) Tidak memberikan informasi, dokumen, dan alat bukti lainnya yang diperlukan MKDKI/MKDKI-P untuk pemeriksaan atas pengaduan dugaan pelanggaran disiplin profesional dokter dan dokter gigi. 
Dalam hal terdapat dokter yang melakukan salah satu dari bentuk pelanggaran disiplin yang sudah ditetapkan dalam Peraturan Konsil Kedokteran Indonesia Nomor 4 Tahun 2011, maka setiap orang/badan hukum yang mengetahui atau merasa kepentingannya dirugikan atas tindakan dokter atau dokter gigi dalam menjalankan praktik kedokteran, dapat melakukan pengaduan kepada Majelis Kehormatan Disiplin Kedokteran Indonesia baik secara tertulis dan/atau lisan.

Atas pengaduan tesebut, kemudian dilakukan pemeriksaan awal untuk memutuskan apakah pengaduan tersebut tidak dapat diterima, ditolak, atau diterima. Dalam hal pengaduan diterima, maka Majelis Kehormatan Disiplin Kedokteran Indonesia membentuk Majelis Pemeriksa Disiplin guna menentukan ada atau tidaknya pelanggaran disiplin dokter dan dokter gigi yang diadukan.

Setelah dilakukan pemeriksaan disiplin, maka Majelis Pemeriksa Disiplin akan menetapkan keputusan terhadap dokter teradu. Keputusan tersebut dapat berupa: (a) dinyatakan tidak ditemukan pelanggaran disiplin dokter dan dokter gigi; (b) dinyatakan dokter teradu terbukti melakukan pelanggaran disiplin profesi dokter dan dokter gigi serta menetapkan sanksi berupa: (i) peringatan tertulis; (ii) rekomendasi pencabutan Surat Tanda Registrasi (STR); atau (iii) kewajiban mengikuti pendidikan dan/atau pelatihan.

Tahap selanjutnya, Majelis Kehormatan Disiplin Kedokteran Indonesia menetapkan keputusan Majelis Pemeriksa Disiplin tentang hasil pemeriksaan terhadap dugaan pelanggaran disiplin dokter dan dokter gigi sebagai keputusan Majelis Kehormatan Disiplin Kedokteran Indonesia. Menurut ketentuan Pasal 60 Ayat (1) Peraturan Konsil Kedokteran Indonesia Nomor 32 Tahun 2015 dikatakan bahwa Keputusan Majelis Kehormatan Disiplin Kedokteran Indonesia ini bersifat final dan berkekuatan tetap. Namun dalam implementasinya, tidak jarang ditemukan bahwa terhadap keputusan Majelis Kehormatan Disiplin Kedokteran Indonesia ini diajukan gugatan ke pengadilan tata usaha negara oleh dokter teradu yang telah dinyatakan telah terbukti melakukan pelanggaran disiplin profesi dokter dan dokter gigi. Sebagai contoh, Putusan Pengadilan Tata Usaha Negara Jakarta Nomor: 198/G/2013/PTUN-JKT, Putusan Pengadilan Tata Usaha Negara Jakarta Nomor: 84/G/2011/PTUN-JKT, Pengadilan Tinggi Tata Usaha Negara Jakarta Nomor: 242/B/2011/PT.TUN.JKT, dan Putusan Mahkamah Agung Nomor: 298K/TUN/2012.

Diajukannya gugatan terhadap surat keputusan Majelis Kehormatan Disiplin Kedokteran Indonesia ke pengadilan tata usaha negara didasari anggapan bahwa Majelis Kehormatan Disiplin Kedokteran Indonesia merupakan badan atau pejabat tata usaha negara sebagaimana yang tercantum dalam ketentuan Pasal 1 Angka 9 Undang-Undang Nomor 5 Tahun 1986 jo. UndangUndang Nomor 51 Tahun 2009. Ketentuan tersebut menyatakan bahwa "Badan atau Pejabat Tata Usaha Negara adalah badan atau pejabat yang melaksanakan urusan pemerintahan berdasarkan peraturan perundang-undangan. Dengan mengacu pada ketentuan ini, maka tidak sedikit hakim yang berpendapat bahwa Majelis Kehormatan Disiplin Kedokteran Indonesia masuk dalam kategori badan atau pejabat tata usaha negara, karena Majelis Kehormatan Disiplin Kedokteran Indonesia dibentuk berdasarkan amanat dari Undang-Undang Nomor 29 Tahun 2004 tentang Praktik Kedokteran guna menegakkan disiplin profesi dokter dan dokter gigi di Indonesia.

Sebagaimana kita ketahui, Pasal 1 Angka 9 Undang-Undang Nomor 5 Tahun 1986 jo. UndangUndang Nomor 51 Tahun 2009 menyatakan bahwa suatu keputusan tata usaha negara yang dapat dijadikan sebagai obyek sengketa dalam pengadilan tata usaha negara harus merupakan suatu penetapan tertulis yang dikeluarkan oleh badan atau pejabat tata usaha negara yang berisi tindakan hukum tata usaha negara yang berdasarkan peraturan perundang-undangan yang berlaku, yang bersifat konkret, individual, dan final, yang menimbulkan akibat hukum bagi seseorang atau badan 
hukum perdata. Tentu perlu ditelusuri lebih lanjut, apakah keputusan Majelis Kehormatan Disiplin Kedokteran Indonesia telah memenuhi persayaratan tersebut.

Keputusan Majelis Kehormatan Disiplin Kedokteran Indonesia yang menetapkan penjatuhan sanksi kepada dokter yang telah terbukti melakukan pelanggaran disiplin profesi akan diteruskan kepada Konsil Kedokteran Indonesia untuk dilaksanakan, khususnya apabila sanksi disiplin tersebut berupa rekomendasi pencabutan Surat Tanda Registrasi dokter, maka Konsil Kedokteran Indonesia yang melaksanakan sanksi tersebut (Pasal 66 Ayat (2) Peraturan Konsil Kedokteran Indonesia Nomor 32 Tahun 2015). Hal ini dikarenakan kewenangan untuk menerbitkan dan mencabut Surat Tanda Registrasi dokter merupakan kewenangan dari Konsil Kedokteran Indonesia yang merupakan instansi atasan dari Majelis Kehormatan Disiplin Kedokteran Indonesia. Sehingga menurut hemat Penulis, surat keputusan Majelis Kehormatan Disiplin Kedokteran Indonesia yang menjatuhkan sanksi kepada dokter yang telah terbukti melakukan pelanggaran disiplin, belum memiliki akibat hukum bagi dokter yang bersangkutan.

Penulis berpendapat bahwa jika berpedoman pada rumusan ketentuan Pasal 1 Angka 9 UndangUndang Nomor 5 Tahun 1986 jo. Undang-Undang Nomor 51 Tahun 2009, maka keputusan Majelis Kehormatan Disiplin Kedokteran Indonesia tidak memenuhi kriteria untuk dapat dijadikan sebagai obyek sengketa dalam peradilan tata usaha negara. Karena sebagaimana yang telah ditentukan dalam Pasal 2 Undang-Undang Nomor 5 Tahun 1986 jo. Undang-Undang Nomor 9 Tahun 2004, bahwa keputusan tata usaha negara yang masih memerlukan persetujuan dari instansi atasan bukan merupakan keputusan tata usaha negara yang dapat diajukan sebagai obyek sengketa dalam pengadilan tata usaha negara. Dalam hal ini, keputusan Majelis Kehormatan Disiplin Kedokteran Indonesia perihal penjatuhan sanksi disiplin kepada dokter masih harus disampaikan kepada Konsil Kedokteran Indonesia untuk dilaksanakan. Konsil Kedokteran Indonesia sendiri merupakan instansi atasan dari Majelis Kehormatan Disiplin Kedokteran Indonesia.

Namun, pada praktek di persidangan, tidak jarang gugatan yang diajukan oleh dokter yang dijatuhi sanksi disiplin oleh Majelis Kehormatan Disiplin Kedokteran Indonesia, kemudian mengajukan gugatan ke pengadilan tata usaha negara guna membatalkan surat keputusan Majelis Kehormatan Disiplin Kedokteran Indonesia yang berisikan penjatuhan sanksi disiplin kepada dokter. Gugatan tersebut kemudian diterima oleh hakim pengadilan tata usaha negara, baik pada tingkat pertama, tingkat banding, maupun sampai tingkat kasasi. Majelis hakim berpendapat bahwa surat keputusan Majelis Kehormatan Disiplin Kedokteran Indonesia telah memenuhi kriteria sebagai keputusan tata usaha negara yang dapat dijadikan obyek sengketa di pengadilan tata usaha negara.

Hakim tata usaha negara (baik pada tingkat pertama, banding, maupun kasasi) berpandangan bahwa surat keputusan Majelis Kehormatan Disiplin Kedokteran Indonesia telah memenuhi kriteria sebagai keputusan tata usaha negara yang dapat dijadikan sebagai obyek sengketa adalah mengacu pada ketentuan Pasal 87 Undang-Undang Nomor 30 Tahun 2014 tentang Administrasi Pemerintahan. Pasal tersebut memberikan perluasan terhadap ruang lingkup dari keputusan tata usaha negara sebagaimana yang diatur dalam Pasal 1 Angka 9 Undang-Undang Nomor 5 Tahun 1986 jo. Undang-Undang Nomor 51 Tahun 2009. Menurut Pasal 87 Undang-Undang Nomor 30 Tahun 2014, keputusan tata usaha negara harus dimaknai juga sebagai: (a) penetapan tertulis yang juga mencakup tindakan faktual; (b) keputusan badan dan/atau pejabat tata usaha negara di lingkungan eksekutif, legislatif, yudikatif, dan penyelenggara negara lainnya; (c) berdasarkan ketentuan peraturan perundang-undangan dan asas-asas umum pemerintahan yang baik; (d) bersifat final dalam arti luas; (e) keputusan yang berpotensi menimbulkan akibat hukum; dan/atau (f) keputusan yang berlaku bagi warga masyarakat. 
Hakim tata usaha negara memandang bahwa meskipun keputusan Majelis Kehormatan Disiplin Kedokteran Indonesia yang memuat sanksi disiplin bagi dokter, belum menimbulkan akibat hukum karena belum dilaksanakan oleh Konsil Kedokteran Indonesia sebagai instansi atasan dari Majelis Kehormatan Disiplin Kedokteran Indonesia yang memiliki kewenangan untuk mencabut Surat Tanda Registrasi dokter/dokter gigi, namun keputusan tersebut sudah berpotensi menimbulkan akibat hukum. Penafsiran hakim ini didasarkan pada ketentuan Pasal 87 huruf e Undang-Undang Nomor 30 Tahun 2014.

Atas perluasan ruang lingkup dari keputusan tata usaha negara sebagaimana ketentuan Pasal 87 Undang-Undang Nomor 30 Tahun 2014, maka banyak hakim pengadilan tata usaha negara yang menerima gugatan terhadap surat keputusan Majelis Kehormatan Disiplin Kedokteran Indonesia yang berisikan penjatuhan sanksi disiplin kepada dokter atau dokter gigi yang terbukti melakukan pelanggaran disiplin profesi. Padahal jika melihat pada ketentuan Pasal 62 Peraturan Konsil Kedokteran Indonesia Nomor 32 Tahun 2015, jelas dikatakan bahwa keputusan Majelis Kehormatan Disiplin Kedokteran Indonesia merupakan keputusan dalam bidang disiplin profesi dokter dan bukan merupakan keputusan menyangkut bidang hukum, sehingga tidak dapat diartikan bahwa telah terjadi pelanggaran dan/atau kesalahan di bidang hukum. Kondisi yang demikian membuat penegakan disiplin profesi dokter menjadi tidak efektif.

\section{KESIMPULAN DAN SARAN}

Berdasarkan uraian pembahasan sebelumnya, maka ditarik kesimpulan bahwa penegakan disiplin profesi dokter dan dokter gigi seharusnya dipisahkan dari bidang hukum, karena penegakan disiplin ini dimaksudkan untuk melindungi masyarakat, mempertahankan, dan meningkatkan mutu pelayanan kesehatan, serta menjaga kehormatan profesi dokter dan dokter gigi. Namun penegakan disiplin profesi dokter dan dokter gigi ini menemui kendala dengan adanya perluasan ruang lingkup keputusan tata usaha negara sebagaimana yang terdapat dalam Pasal 87 UndangUndang Nomor 30 Tahun 2014. Perluasan keputusan tata usaha negara yang dapat diajukan sebagai obyek sengketa dalam peradilan tata usaha negara ini banyak dimanfaatkan oleh dokterdokter yang dijatuhi sanksi disiplin oleh Majelis Kehormatan Disiplin Kedokteran Indonesia sebagai akibat dari terbuktinya dugaan pelanggaran disiplin yang dilakukan oleh dokter dan dokter gigi. Sanksi disiplin tersebut dituangkan dalam surat keputusan Majelis Kehormatan Disiplin Kedokteran Indonesia yang berisikan rekomendasi pencabutan Surat Tanda Registrasi dokter dan dokter gigi. Sanksi tersebut kemudian dilaporkan ke Konsil Kedokteran Indonesia untuk dilaksanakan. Meskipun surat keputusan tersebut secara nyata belum menimbulkan akibat hukum bagi dokter yang dijatuhi sanksi (karena belum keputusan tersebut belum dilaksanakan oleh Konsil Kedokteran Indonesia), namun dengan adanya ketentuan Pasal 87 huruf e Undang-Undang Nomor 30 Tahun 2014 membuat surat keputusan Majelis Kehormatan Disiplin Kedokteran Indonesia sangat mungkin untuk diajukan sebagai obyek sengketa di pengadilan tata usaha negara. Dalam konteks ini, hakim pengadilan tata usaha negara melakukan penemuan hukum dengan cara menginterpretasikan ketentuan Pasal 87 huruf e Undang-Undang Nomor 30 Tahun 2014, sehingga gugatan terhadap surat keputusan Majelis Kehormatan Disiplin Kedokteran Indonesia di pengadilan tata usaha negara diterima oleh hakim. 
Maka dari itu, Penulis mengajukan saran agar penegakan disiplin profesi dokter dan dokter gigi seharusnya bersifat otonom dan independen, sebagaimana yang diamanatkan Pasal 55 Ayat (2) dan Ayat (3) Undang-Undang Nomor 29 Tahun 2004. Karena ketentuan tersebut sudah dengan sangat tegas dinyatakan bahwa penegakan disiplin oleh Majelis Kehormatan Disiplin Kedokteran Indonesia bersifat independen dan otonom, serta keputusan yang dihasilkan pun bersifat final dan mengikat bagi para pihak (Pasal 60 Ayat (1) Peraturan Konsil Kedokteran Indonesia Nomor 32 Tahun 2015. Hakim pengadilan tata usaha negara seharusnya menolak pengajuan surat keputusan Majelis Kehormatan Disiplin Kedokteran Indonesia yang menjatuhkan sanksi kepada dokter atau dokter gigi, karena penegakan disiplin bukanlah merupakan kewenangan dari pengadilan tata usaha negara.

\section{Ucapan Terima Kasih (Acknowledgement)}

Penulis menyampaikan ucapan terima kasih kepada Direktorat Penelitian dan Pengabdian kepada Masyarakat Universitas Tarumanagara (DPPM UNTAR) selaku penyedia dana dalam penelitian ini. Selain itu juga Penulis berterima kasih kepada Fakultas Hukum Universitas Tarumanagara yang telah mendukung terlaksananya penelitian ini, serta kepada para narasumber dalam penelitian ini yang meliputi Pengurus Besar Ikatan Dokter Indonesia (PB IDI), Konsil Kedokteran Indonesia (KKI), Majelis Kehormatan Disiplin Kedokteran Indonesia (MKDKI), Mahkamah Agung Republik Indonesia, dan Pengadilan Tinggi Tata Usaha Negara Jakarta.

\section{REFERENSI}

Chazawi, A. (2016). Malapraktik Kedokteran. Sinar Grafika, Jakarta.

Is, M. S. (2015). Etika Hukum Kesehatan (Teori dan Aplikasinya di Indonesia). Kencana Prenada Media Group, Jakarta.

Ikatan Dokter Indonesia. Kode Etik Kedokteran Indonesia Tahun 2012.

Indonesia. Undang-Undang Nomor 5 Tahun 1986 tentang Peradilan Tata Usaha Negara. .Undang-Undang Nomor 9 Tahun 2004 tentang Perubahan Atas Undang-Undang Nomor 5 Tahun 2986 tentang Peradilan Tata Usaha Negara. . Undang-Undang Nomor 29 Tahun 2004 tentang Praktik Kedokteran. . Undang-Undang Nomor 51 Tahun 2009 tentang Perubahan Kedua Atas Undang-

Undang Nomor 5 Tahun 1986 tentang Peradilan Tata Usaha Negara. . Putusan Pengadilan Tata Usaha Negara Jakarta Nomor: 84/G/2011/PTUN-JKT. . Pengadilan Tinggi Tata Usaha Negara Jakarta Nomor: 242/B/2011/PT.TUN.JKT. . Putusan Mahkamah Agung Nomor: 298K/TUN/2012.

. Putusan Pengadilan Tata Usaha Negara Jakarta Nomor: 198/G/2013/PTUN-JKT,

Konsil Kedokteran Indonesia. Peraturan Konsil Kedokteran Indonesia Nomor 1 Tahun 2011 tentang Organisasi dan Tata Kerja Konsil Kedokteran Indonesia.

. Peraturan Konsil Kedokteran Indonesia Nomor 3 Tahun 2011 tentang Organisasi dan

Tata Kerja Majelis Kehormatan Disiplin Kedokteran Indonesia dan Majelis Kehormatan Disiplin Kedokteran Indonesia tingkat Provinsi.

Peraturan Konsil Kedokteran Indonesia Nomor 4 Tahun 2011 tentang Disiplin

Profesional Dokter dan Dokter Gigi.

. Peraturan Konsil Kedokteran Indonesia Nomor 32 Tahun 2015 tentang Tata Cara Penanganan Kasus Dugaan Pelanggaran Disiplin Dokter dan Dokter Gigi.

Marzuki, P. M. (2015). Penelitian Hukum. Kencana Prenada Media Group, Jakarta.

ND, M. F., \& Achmad, Y. (2013). Dualisme Penelitian Hukum Normatif dan Empiris. Pustaka Belajar, Yogyakarta. 
Siswati, S. (2013). Etika dan Hukum Kesehatan (Dalam Perspektif Undang-Undang Kesehatan). Raja Grafindo Persada, Jakarta.

Sutiyoso, B. (2012). Metode Penemuan Hukum (Upaya Mewujudkan Hukum yang Pasti dan Berkeadilan). UII Press, Yogyakarta.

Triwibowo, C. (2014). Etika dan Hukum Kesehatan. Nuha Medika, Yogyakarta. 